\author{
Yamin Rengen \\ Staff Bagian Pendidikan Anak Usia Dini \\ (PAUD) \\ Dinas Pendidikan, Pemuda dan \\ Olahraga Kabupaten Fakfak Provinsi \\ Papua Barat \\ Email : yaminrengen@yahoo .com
}

https://doi.org//0.18196/jgpp.4388

\section{KELEMBAGAAN MAJELIS RAKYAT PAPUA BARAT (MRP-PB) DALAM OTONOMI KHUSUS 2017}

\begin{abstract}
ABSTRAK
Berdasarkan Undang-Undang Nomor 21 Tahun 2001 tentang Otonomi Khusus Bagi Propinsi Popua, kepada Provinsi dan Kabupaten/kota di Provinsi Papua diberikan Otonomi Khusus, yakni bentuk otonomi yang hanya diberikan kepada Provinsi Papua dan Provinsi Nanggroe Aceh Darusalam. Dalam bidang keuangan, khususan ini diwujudkan dengan pemberian Dana Otonomi Khusus yang berupa dana penerimaan khusus dan dana bagi hasil minyak bumi dan gas alam yang presentasenya lebih besar dibandingkan daerah lain di Indonesia. Dana otonomi khusus yang besar jumlahnya tidak sebanding dengan kualitas sumber daya manusia yang mengelola dana tersebut. Hal ini bisa menghambat efektivitas dalam mencapai tujuan pemberian otonomi khusus, yaitu peningkatan pendidikan dan kesehatan (gizi) masyarakat asli Papua.

Sifat penelitian ini adalah deskriptif analisis dengan menerapkan metode studi kepustakaan dan wawancara tidak berstruktur dengan pejabat di lingkungan Direktorat Fasilitas Dana Perimbangan Direktorat Jenderal Bina Administrasi Keuangan Daerah Departemen Dalam Negeri. Hasil penelitian menunjukkan bahwa dana otonomi khusus ternyata tidak memberikan keseimbangan fiskal, baik vertikal maupun horizontal, bahkan sebaliknya menambah kesenjangan fiskal, mengingat sebagian besar kapasitas fiskal kabupaten/kota di provinsi Papua termasuk kategori sedang dan tinggi (hanya 2 yang berkapasitas fiskal rendah). Selain itu, terdapat peraturan pelaksanaan pengelolaan dana otonomi khusus yang saling bertentangan sehingga dapat menimbulkan perbedaan persepsi. Oleh karena itu perlu diperjelas aturan mengenai pengelolaan dana otonomi khusus sehingga dapat dijadikan pedoman dalam pelaksanaannya.
\end{abstract}

Kata kunci: Kelembagaan, Majelis Rakyat Papua, Otonomi Khusus

\title{
PENDAhUluaN
}

Otonomi daerah merupakan salah satu landasan hukum bagi daerah untuk melaksanakan pembangunan daerah yang lebih aspiratif berdasarkan prakarsasendiri, dengan memanfaatkan seluruh potensi yang dimilikinya. UndangUndang Nomor 22 Tahun 1999 tentang Pemerintahan Daerah,bagi Provinsi Papua, dinilai belum sepenuhnya mengakomodir seluruh kepentingan daerah. Karakteristik daerah yang sangat berbeda dengan beberapadaerah lain di wilayah Negara Kesatuan Republik Indonesia, permasalahan-permasalahanyang belum terselesaikan, mengharuskan adanya perlakuankhusus bagi Provinsi Papua.

Otonomi Khusus bagi Provinsi Papua pada dasarnya adalah pemberian wewenang yang lebih luas bagi Provinsi dan rakyat Papua untuk mengatur danmengurus diri sendiri di dalam kerangka Negara Kesatuan Republik Indonesia. Wewenang yang lebih luas berarti pula tanggungjawab yang lebih besar bagiProvinsi dan rakyat Papua, untuk menyelenggarakan pemerintahan danmengatur 
Demanfaatan kekayaan alam di Provinsi Papua untuk sebesar-besarnyabagi kemakmuran rakyat Papua sebagai bagian dari rakyat Indonesiasesuai dengan peraturan perundang-undangan.

MRPB berkedudukan sebagai lembaga representasi kultural orang asli Papua yangmemiliki wewenang tertentu dalam rangka perlindungan hak-hak orang asliPapua dengan berlandaskan pada penghormatan terhadap adat dan budaya,pemberdayaan perempuan, dan pemantapan kerukunan hidup beragama. Pembentukan MRP ini dilatarbelakangi oleh beberapa alasan :

1. Hak-hak politik orang asli Papua dan kaum perempuan cenderung diabaikan;

2. Representasi politik orang asli Papua dan kaum perempuan di lembagalembagapolitik (parpol/legislatif) tidak cukup signifikan;

3. Aspirasi politik orang asli Papua dan kaum perempuan cenderung tidakterakomodir;

4. Tingkat partisipasi politik orang asli Papua dan kaum perempuan tergolong relatif rendah;

5. Komitmen untuk menghormati adat dan budaya, memberdayakan kaumperempuan, dan memantapkan kerukunan hidup beragama;

6. Komitmen untuk melakukan rekonsiliasi antara sesama orang asli Papua,maupun orang asli Papua dengan sesama penduduk Provinsi Papua.

Kehadiran MRP sesungguhnya diharapkan dapat merumuskan kebijakan yang bernilai strategis sebagai upaya untuk meningkatkan pelayanan (service), pemberdayaan (empowerment), memperkuat tatakelola pemerintahan (good governance), serta dalam rangka akselarasi pembangunan (acceleration development), namun apabila proses pembentukannya tidak di laksanakan secara tepat dan bijaksana, justru berpotensi untuk memicu konflik yang lebih luas dan berbagai permasalahan lainnya dikalangan masyarakat asli Papua. Kebijakan publik yang dikeluarkan oleh pemerintah harus transparan, efektif dan efisien, serta mampu menjawab ketentuan dasar keadilan. Sebagai bentuk penyelenggaraan negara yang baik maka harus keterlibatan masyarakat di setiap jenjang proses pengambilan keputusan (Goto Kuswanto, 2012).

Dari beberapa permasalahan terkait pelaksanaan tugas MRP yang telah dipaparkan diatas, maka penulis merasa tertarik untuk melakukan penelitian terkait dengan pelaksanaan fungsi MRP dalam memperkuat tatakelola pemerintahan di Provinsi Papua Barat. Pelaksanaan fungsi tersebut 
secara otomatis berdampak pada kualitas pelayanan publik menjadi semakin baik, angka korupsi menjadi semakin rendah, pemerintah menjadi semakin peduli dengan kepentingan warganya dan berbagai permasalahan lain yang dapat diminimalisir.

\section{A. KERANGKA TEORI}

1. Majelis Rakyat Papua

MRP adalah lembaga yang termasuk dalam susunan pemerintahan daerah dalam UU Otsus, Pasal 5 ayat (2) Dalam rangka penyelenggaraan Otonomi Khusus di Provinsi Papua dibentuk Majelis Rakyat Papua yang merupakan representasi kultural orang asli Papua yang memiliki kewenangan tertentu dalam rangka perlindungan hak-hak orang asli Papua, dengan berlandaskan pada penghormatan terhadap adat dan budaya, pemberdayaan perempuan, dan pemantapan kerukunan hidup beragama; ayat (3) MRP dan DPRP berkedudukan di ibu kota Provinsi.

\section{Good Governance}

Menurut bahasa Good Governance berasal dari dua kata yang diambil dari bahasa inggris yaitu Good yang berarti baik, dan governance yang berarti tata pemerintahan. Dari pengertian tersebut good governance dapat diartikan sebagai tata pemerintahan yang baik, atau pengelolaan/ penyelenggaraan kepemerintahan yang baik.

Dalam menciptakan tata pemerintahan yang baik sangat tergantung dari ketiga lembaga yang menyusun governance tersebut yaitu pemerintah (government), dunia usaha (swasta), dan masyarakat.Ketiga domain itu harus saling berinteraksi antara satu dengan yang lainnya.Ketiga lembaga ini harus menjaga kesinergian dalam rangka mencapai tujuan, karena ketiga domain ini merupakan sebuah sistem yang saling ketergantungan dan tidak dapat dipisahkan.

Jika mengacu pada program World Bank dan United Nation Development Program (UNDP), orientasi pembangunan sektor public adalah untuk menciptakan good governance.Pengertian good governance sering diartikan sebagai kepemerintahan yang baik.Gunawan Sumodiningrat (1999: 251) menyatakan good governance adalah upaya pemerintahan yang amanah dan untuk menciptakan good governance pemerintahan perlu didesentralisasi dan sejalan dengan kaidah penyelenggaraan pemerintahan yang bersih dan bebas korupsi, kolusi, dan nepotisme.

Sementara itu, World Bank mendefinisikan good governance sebagai suatu penyelenggaraan manajemen pembangunan yang solid dan bertanggung jawab yang sejalan dengan prinsip demokrasi dan pasar yang 
D12 efisien, penghindaran salah alokasi dana investasi, dan pencegahan korupsi baik secara politik maupun administrasi, menjalankan disiplin anggaran serta penciptaan legal and political framework bagi tumbuhnya aktivitas usaha (Mardiasmo, 2002: 18).

3. Teori Kelembagaan

Kelembagaan berasal dari kata lembaga, yang berarti aturan dalam organisasi atau kelompok masyarakat untuk membantu anggotanya agar dapat berinteraksi satu dengan yang lain untuk mencapai tujuan yang diinginkan (Ruttan dan Hayami, Journal Of Development Studies: 1984). Kelembagaan berasal dari kata lembaga, yang berarti aturan dalam organisasi atau kelompok masyarakat untuk membantu anggotanya agar dapat berinteraksi satu dengan yang lain untuk mencapai tujuan yang diinginkan. (Ruttan dan Hayami, Journal Of Development Studies: 1984).

Menurut Scott (2008: 36), teori kelembagaan baru (Neoinstitutional Theory) adalah tentang bagaimana menggunakan pendekatan kelembagaan baru dalam mempelajari sosiologi organisasi. Akar teoritisnya berasal dari teori kognitif, teori kultural, serta fenomenologi dan etnometodologi. Ada 3 elemen analisis yang membangun kelembagaan walau kadang-kadang ada yang dominan, tapi mereka bekerja dalam kombinasi. Ketiganya datang dari perbedaan cara pandang terhadap sifat realitas sosial dan keteraturan sosial dalam tradisi sosiologi sebelumnya. Ketiga elemen tersebut adalah aspek regulatif, aspek normatif, dan aspek kultural-cognitif.

Kelembagaan berisi sekelompok orang yang bekerjasama dengan pembagian tugas tertentu untuk mencapai suatu tujuan yang diinginkan.Tujuan peserta kelompok dapat berbeda, tapi dalam organisasi menjadi suatu kesatuan. (Bobi, 2002:1). Kelembagaan menurut beberapa ahli, sebagian dilihat dari kode etik dan aturan main, sedangkan sebagian lagi dilihat pada organisasi dengan struktur, fungsi dan manajemennya.Saat ini kelembagaan biasanya dipadukan antara organisasi dan aturan main.Kelembagaan merupakan suatu unit sosial yang berusaha untuk mencapai tujuan tertentu dan menyebabkan lembaga tunduk pada kebutuhan tersebut.(Amitai Etzioni, 1982:7).

Bentuk resmi suatu lembaga yaitu lembaga garis (line organization, military organization); lembaga garis dan staf (line and staff organization); lembaga fungsi (functional organization). Lembaga garis bertanggung jawab pada satu atasan dan bertanggung jawab penuh pada tugasnya.Lembaga garis dan staf wajib melaporkan laporan kegiatan pada satu atasan, pemberian nasehat dari beberapa atasan kepada satu atasan yang lebih tinggi, dan 
lembaga fungsi bertanggung jawab kepada lebih dari satu atasan yang sesuai dengan spesialisasi masingmasing (Phil A., Susanto, 1989: 25).

Tiga jenis dasar dari lembaga yaitu: Lembaga Sistem Otoriter, terdapat dua tingkatan kedudukan, atasan dan bawahan. Atasan bertugas untuk membina dan menguasai yang lain, suka maupun tidak suka, biasanya ditentukan oleh keturunan, kekayaan, umur, pendidikan, kedudukan/kemampuan, hal ini menyebabkan atasan memutuskan segala sesuatu sendiri; Lembaga Sistem Demokrasi, semua anggota memiliki hak dan kewajiban yang sama dan seimbang, pemimpin berfungsi sebagai yang satu dari yang sama; Lembaga Sistem "Biarkan Saja" (claissez faire) semua anggota sama tingkat kedudukan dan fungsi sehingga menyebabkan pemimpin tidak memiliki arti dan tidak mempunyai fungsi (Wiryanto $\mathrm{F}$, 1986: 101).

Tiga pilar utama dari lembaga W. Richard Scott. Tiga pilar tersebut adalah regulatif, normatif dan kognitif budaya (W. Richard Scott, 2008 : 52).

(1) Regulatif adalah suatu peraturan yang ada dalam suatu lembaga, peraturan tersebut terdiri dari kekuatan, kebijakan-kebijakan, dan sanksi yang telah dibuat oleh lembaga itu. Artinya dengan regulative tersebut, maka memungkinkan lembaga tersebut dalam aksinya dapat memberikan lisensi, kekuasaan khusus, dan manfaat bagi lembaga itu sendiri.

(2) Normatif adalah suatu konsep norma-norma yang digunakan dalam suatu lembaga, diaman norma tersebut merupakan pedoman dasar bagi kebijakan-kebijakan lembaga. Norma dapat membangkitkan suatu perasaan kuat untuk para anggota dari lembaga tersebut. Konsepsi normatif dalam suatu lembaga menekankan dalam mempengaruhi stabilitas sosial dan norma-norma yang baik bagi masyarakat.

(3) Kognitif budaya yaitu pemikiran tentang suatu budaya yang ada dalam lembaga. Kognitif budaya diantaranya berisi tentang paham, keyakinan, pengikat, dan bersifat isomorf. Kognitif budaya dalam teori ini akan sangat penting, karena kognitif budaya dalam teori ini lebih bisa berubah-ubah dibandingkan dengan dua pilar lain yaitu regulatif dan normatif. .

Dari penjelasan diatas dapat ditarik suatu variabel penelitian terkait dengan lembaga yang didalamnya terdiri dari instrument seperti sistem simbolik, sistem relasi, rutinitas, dan artifact. Dimana dari instrument 
11 tersebut mencangkup tentang sistem regulasi, normative, dan kultur budaya suatu lembaga.

\section{Diagram 1.1 Kerangka berpikir Penelitian}

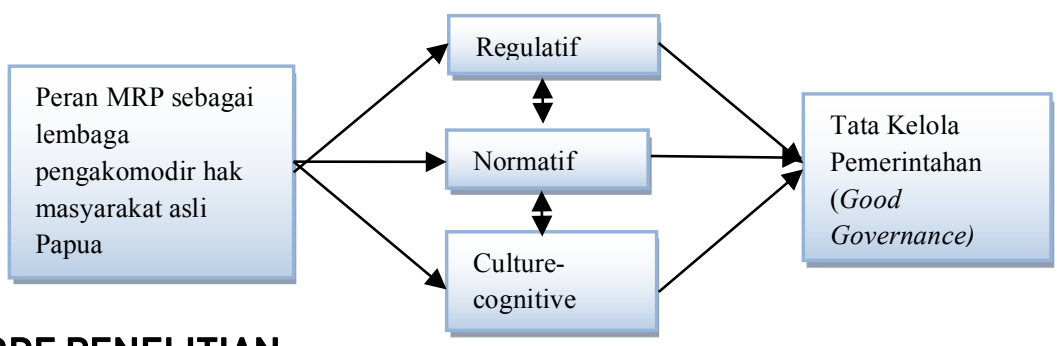

\section{METODE PENELITIAN}

Dalam penelitian ini penulis mengunakan pendekatan penelitian deskristif kualitatif yang perkuat oleh metode kuantitatif. Metode ini dipilih karena peneliti pada akhirnya akan memberikan penjelasan berdasarkan masalah pokok yang telah di tentukan dan menganalisis data secara kualitatif dan kuantitatif. Analisa data kuantitatif karena peneliti juga menggunakan kuesioner untuk memperoleh secara rinci tentang fenomenafenomena apa yang di teliti dan memberikan gambaran tentang bagaimana proses fenomena serta dampaknya berdasarkan fokus penelitian ini.

\section{HASIL DAN PEMBAHASAN}

\section{Kewenangan MRP Papua Barat dalam Tata Kelola Pemerintahan}

\section{Elemen Regulatif}

Sistem kewenangan yang diberikan oleh pemerintah pusat kepada Majelis Rakyat Papua Barat secara jelas telah di atur dalam aturan dan hukum selama masa jabatan 5 (lima) tahun, sehingga kita dapat mengetahui sejauh mana arah kebijakan maupun kepentingan lembaga dalam memperjuangkan hak asli orang Papua barat. Pe Perlu diketahui bahwa agenda utama dari kewenangan MRP Papua Barat terdiri dari 3 (tiga) agenda yaitu elemen regulatif, normatif, dan kultral-kognitif dalam program kerja lembaga meliputi: Rekonsiliasi, Agen Pengawal Pembangunan dan Penguatan Lembaga Adat.

Masyarakat hukum adat adalah masyarakat yang berdasarkan hukum adat atau adat istiadat seperti desa, marga, nagari, huta, dan lain-lain. Masyarakat hukum adalah kesatuan masyarakat yang bersifat teritorial atau genealogis yang memiliki kekayaan sendiri, dapat bertindak ke dalam atau ke luar sebagai satu kesatuan hukum (subjek hukum) yang mandiri. Kesatuan- 
kesatuan masyarakat hukum ini mempunyai hak hidup yang sederajat dan sama pentingnya dengan pemerintahan kabupaten maupun kota, Mereka berhak mendapat perlakuan dan diberi kesempatan berkembang sebagai subsistem Negara Kesatuan Republik Indonesia. Prinsip badan perwakilan dipilih langsung dalam suatu pemilihan umum (Pasal 18 ayat (3)). Ketentuan ini memberikan implikasi hukum bahwa keanggotaan DPRD tidak ada yang diangkat. Prinsip mengakui dan menghormati pemerintahan daerah yang bersifat khusus dan istimewa (Pasal 18 B ayat (1)).

Hak politik orang asli Papua tidak lepas dari nilai-nilai norma yang diperjuangkan selama ini. Pada elemen normatif MRP sebagai lembaga yang merepresentasikan norma maupun adat dan menjunjung tinggi hak orang asli Papua. Misalkan MRP Papua Barat memperjuangkan dan mendorong agar recruitmen partai politik memperioritaskan orang asli Papua dan mendapatkan pertimbangan dari lembaga MRP. Karena yang menjadi bahan pertimbangan lembaga adat seperti MRP adalah memilih orang-orang yang dapat membawa aspirasi serta faham akan nilai-nilai yang diperjuangkan sesuai dengan adat dan istiadat yang berlaku selama ini di tanah Papua yang selalu mejujung tinggi nilai kekompakan dan kekeluargaan.

Alat Kelengkapan MRP terdiri dari :

a. Pimpinan;

b. Kelompok Kerja-Kelompok Kerja; dan

c. Dewan Kehormatan.

Aksi kultual-kognitif dibuktikan dengan dengan menjawab permasalahan dengan agenda merekonsiliasikan hak-hak orang asli Papua . adapun yang menajadi agenda rekonsliasi diataranya meliputi:

a. Mendorong terciptanya rekonsiliasiorang asli Papua menurut marga dari setiap suku-suku dan wilayah budaya agar saling menghargai dan mengakui antar sesama suku asli Papua dan suku-suku asal daerah Indoneesia lainya yang hidup berdampingan di atas Tanah Papua sebaga Tanah Damai.

b. Mendorong terlaksananya Gerakan Pemulihan bagi orang asli Papua dan non Papua di Provisi Papua barat. Pemulihan ini dilakukan dalam segala bidang kehidupan setiap hari. Dengan pemulihan Doa Pengampunan bagi arwah para leluhur orang asli Papua (suku-Suku Asli Papua) hingga generasi muda sekarang. Doa perdamaian dan pemulihan melalui penegakan etika dan moral oaring asli Papua.

c. Menjembatani terbentuknya Komisi Kebenaran dan Rekonsiliasi (KKR) untuk memfasilitasi terjadinya rekonsiliasi di setiap marga dari suku- 
suku asli Papua, orang asli Papua dengan suku-suku dari daerah lainya di Indonesia, orang asli Papua dengan Institusi pemerintah dan TNI /POLRI mulai dari Pusat sampai ke Daerah.

d. Mendorong Pengadilan Adat dan Pengadilan HAM untuk menyelesaikan pelanggaran HAM terhadap orang asli Papua sejak integrasi ke Republik Indonesia, tanggal Mei 1963 hingga sekarang. Pengadilan Adat berkedudukan di setiap wilayah permungkiman orang asli Papua. Sedangkan Pengadilan HAM berkedudukan di Ibu Kota Provinsi Papua Barat.

e. Mendorong berbagai pokok pikiran untuk pembuatan peraturan daerah provinsi (Perdasi) dan peraturan daerah khusus (Perdasus) tentanh hakhak dasar orang asli Papua seperti diamanatkan oleh undang-undang Otonomi Khusus Papua.

Kebijakan desentralisasi yang diterapkan di Provinsi Papua merupakan refleksi dari pendekatan desentralisasi yang "asymetric". Artinya kebijakan desentralisasi yang diterapkan di Provinsi tersebut tidaklah simetris dengan desentralisasi di Provinsi lainnya di Indonesia. Pendekatan "asymetric" dilakukan untuk mengakomodasikan perbedaan yang tajam yang terjadi di daerah-daerah khusus tersebut dengan yang berlaku umum di bagian lain dari negara yang bersangkutan. Dengan penerapan kebijakan tersebut kekhususan daerah dapat diakomodasikan tanpa harus menciptakan separatisme dalam bentuk pemisahan diri dari negara induknya.

Dengan demikian pendekatan desentralisasi di Provinsi Papua pada hakekatnya tetap dimaksudkan untuk mencapai tujuan pelaksanaan desentralisasi dan Otonomi Daerah itu sendiri. Provinsi Papua terdiri atas Daerah Kabupaten dan Daerah Kota yang masing-masing sebagai Daerah Otonom. Daerah Kabupaten/ Kota terdiri atas sejumlah distrik. Distrik terdiri atas sejumlah kampung atau yang disebut dengan nama lain. Berdasarkan Pasal 4 ayat (1) Undang-Undang Nomor 21 Tahun 2001, kewenangan Provinsi Papua mencakup kewenangan dalam seluruh bidang pemerintahan, kecuali kewenangan bidang politik luar negeri, pertahanan keamanan, moneter dan fiskal, agama, dan peradilan serta kewenangan tertentu di bidang lain yang ditetapkan sesuai dengan peraturan perundangundangan.

Kewenangan tertentu di bidang lain yang dimaksud adalah kewenangan Pemerintah yang meliputi: kebijakan tentang perencanaan nasional dan pengendalian pembangunan nasional secara makro, dana perimbangan keuangan, sistem administrasi negara dan lembaga 
perekonomian negara, kewenangan pembinaan dan pemberdayaan sumber daya manusia, pendayagunaan sumber daya alam serta teknologi tinggi yang strategis, konservasi dan standardisasi nasional Pembagian kekuasaan (sharing of power) dalam konteks Otonomi Khusus Provinsi Papua tidak saja menyangkut hubungan pusat dan daerah, tetapi termasuk juga bagaimana kekuasaan dan kewenangan itu dibagi secara baik di dalam Provinsi Papua sendiri.

Otonomi Khusus Papua berarti bahwa ada hubungan hirarkis antara pemerintah tingkat Provinsi dan Kabupaten/ Kota, namun pada saat yang sama Provinsi, Kabupaten/ Kota dan Kampung masing-masing adalah daerah otonom yang memiliki kewenangannnya sendiri-sendiri. Prinsip yang dianut adalah bahwa kewenangan perlu diberikan secara proporsional ke bawah, terutama untuk berbagai hal yang langsung berkaitan dengan masyarakat. Hal ini konsisten dengan salah satu prinsip dasar otonomi yaitu menempatkan sedekat-dekatnya penyelenggaraan pemerintahan dan pembangunan kepada rakyat. Karena itu, di dalam konteks Otonomi Khusus Provinsi Papua, fungsi-fungsi pengaturan berada di tingkat Provinsi sedangkan fungsi-fungsi dan kewenangan pelayanan masyarakat diberikan sebesar-besarnya kepada Kabupaten/ Kota dan Kampung (Tim Bentukan Gubernur Provinsi Papua, 2001).

Untuk menyelenggarakan pemerintahan yang demokratis, profesional dan bersih, sekaligus memiliki ciri-ciri kebudayaan dan jati diri rakyat Papua, serta mengakomodasi sebanyak mungkin kepentingan penduduk asli Papua, dibentuk empat badan/ lembaga, yaitu lembaga eksekutif, lembaga legislatif, lembaga adat, dan lembaga peradilan. Pasal 5 ayat (1) Undang-Undang Nomor 21 Tahun 2001 menyebutkan bahwa Pemerintahan Daerah Provinsi Papua terdiri atas DPRP (Dewan Perwakilan Rakyat Papua) sebagai badan legislatif, dan Pemerintah Provinsi sebagai badan eksekutif. Lembaga eksekutif di tingkat propinsi dipimpin oleh seorang Gubernur dan di tingkat Kabupaten/ Kota dipimpin oleh Bupati atau Walikota.

Lembaga eksekutif berfungsi untuk melaksanakan tugas-tugas pemerintahan. Di Kabupaten/ Kota dibentuk DPRD Kabupaten dan DPRD Kota sebagai badan legislatif serta Pemerintah Kabupaten/Kota sebagai badan eksekutif. Pemerintah Kabupaten/ Kota terdiri atas Bupati/ Walikota beserta perangkat pemerintah Kabupaten/ Kota lainnya. Di Kampung dibentuk Badan Musyawarah Kampung dan Pemerintah Kampung atau dapat disebut dengan nama lain. 
51. Berbicara tentang Otonomi Khusus Papua, hak-hak politik masyarakat adat dan penduduk asli Papua dilindungi dengan diciptakannya suatu kamar tertentu di dalam parlemen Propinsi Papua yang disebut Majelis Rakyat Papua (MRP). Seperti halnya DPRD, Majelis Rakyat Papua (MRP) juga berkedudukan di Provinsi. Pemilihan anggota MRP dilakukan oleh anggota masyarakat adat, masyarakat agama, dan masyarakat perempuan. Majelis Rakyat Papua (MRP) beranggotakan orang-orang asli Papua yang terdiri atas wakil-wakil adat, wakil-wakil agama, dan wakil-wakil perempuan yang jumlahnya masing-masing sepertiga dari total anggota MRP.

Masa keanggotaan MRP adalah 5 (lima) tahun. Majelis Rakyat Papua (MRP) mewakili orang-orang asli Papua dan bertanggung jawab mewujudkan perlindungan dan pengembangan hak-hak orang-orang asli Papua. Oleh karena itu, keanggotaan MRP harus jelas keterwakilannya, harus dikenal oleh, dan mengenal dengan baik rakyat yang diwakilinya. Anggota MRP harus terus berusaha untuk menjaga agar hubungan dengan konstituennya itu terus menerus ditingkatkan.

Hal-hal praktis yang dapat dilakukan antara lain bahwa setiap anggota MRP harus sering kembali ke daerah/ komunitas darimana ia berasal agar dapat terus merasakan dan menjiwai pergumulan masyarakat yang diwakilinya. Mengenai kapabilitas mengacu pada penguasaan kemampuan teknis, anggota MRP tidak cukup berbekal status sebagai seorang wakil masyarakat, tetapi harus memiliki kemampuan-kemampuan berikut ini :

1. Memahami dengan baik masalah, tantangan dan peluang pembangunan orang-orang asli Papua dalam kaitannya dengan konteks sosial-politik lokal, nasional dan global, sehingga mampu dengan seksama menguji Rancangan-Rancangan Perdasus yang dimasukkan oleh DPRP dan Gubernur. Hanya dengan memiliki kemampuan seperti ini MRP dengan tepat dan taktis menerima, menolak, atau meminta Rancangan Perdasus yang dimasukkan itu diperbaiki.

2. Memiliki kemampuan berdiplomasi dan berintegritas, terutama ketika harus membahas hal-hal sensitif, seperti soal lambang-lambang Provinsi Papua (bendera dan lagu), penyelesaian masalah-masalah HAM, klarifikasi sejarah Papua dalam NKRI, perlindungan dan penghargaan terhadap hak-hak masyarakat adat, perlindungan HAM, pelaksanaan kewenangan-kewenangan pemerintah pusat di Papua dengan kekhususan, dan sebagainya. 
3. Mampu untuk memahami arti dan implikasi angka-angka yang tertera dalam rancangan anggaran yang diajukan oleh DPRP dan Gubernur, terutama untuk memastikan bahwa rancangan anggaran tersebut benarbenar sesuai dengan amanat Undang-Undang Nomor 21 Tahun 2001, antara lain adalah untuk memberdayakan status sosial-ekonomi dan memantapkan kebudayaan orang-orang asli Papua, serta penyelesaian berbagai masalah di waktu lalu.

4. Mampu untuk mendengarkan, menampung dan mengolah masukan, saran, keluhan, bahkan protes yang disampaikan oleh para konstituen untuk diteruskan ke pihak-pihak yang berkompeten, dan memastikan bahwa hal-hal tersebut benar-benar ditindaklanjuti. Selain itu, setiap anggota MRP harus mampu pula untuk menjelaskan dengan baik dan benar setiap keputusan yang diambil sehingga rakyat sungguh-sungguh merasa bahwa suara mereka telah didengar, dan bahwa mereka secara substansial dilibatkan dalam setiap proses pengambilan keputusan yang berdampak pada kehidupan mereka.

5. Selain persyaratan representasi dan kapabilitas, maka kualifikasi terakhir yang harus dimiliki oleh setiap anggota MRP adalah integritas diri yang kokoh. Rakyat Papua menginginkan para anggota MRP bebas dari korupsi, kolusi dan nepotisme (Agus Sumule, 2003 : 82 - 84).

Tugas dan kewenangan Majelis Rakyat Papua (MRP), dapat dikatakan bahwa apabila tidak ada Majelis Rakyat Papua (MRP) yang mempunyai kewenangan dalam melindungi hak-hak orang asli Papua, dengan berlandaskan penghormatan terhadap adat dan budaya, pemberdayaan perempuan dan pemantapan kehidupan kerukunan hidup beragama, maka tidak ada Otonomi Khusus Papua. Dengan demikian, dapat dikatakan bahwa Majelis Rakyat Papua (MRP) sebagai representasi kultural orang asli Papua adalah lembaga yang menentukan penyelenggaraan dan eksistensi Otonomi Khusus di Papua. Hal ini karena Majelis Rakyat Papua (MRP), dilihat dari prinsip dasar pemerintahan, mempunyai posisi tertentu dan khas serta menjadi bagian yang tidak terpisahkan dalam UndangUndang Nomor 21 Tahun 2001 tentang Otonomi Khusus bagi Provinsi Papua. Majelis Rakyat Papua (MRP) tidak maksudkan sebagai super body atau lembaga yang mempunyai kekuasaan sangat tinggi. Tujuan Majelis Rakyat Papua (MRP) adalah memberikan kontribusi dalam proses pembangunan di Papua dengan memperhatikan nilai-nilai yang ada di Provinsi Papua.

\section{Elemen Kultural-Kognitif}


516 Untuk menghindari resetensi yang ditimbulkan oleh koflik yang begitu kuat, MRP selaku lembaga adat berusaha memberikan pandangan kepada masyarakat Papua yang tengah kerisis moral, krisis kepercayaan, kehilangan roh, dan arah. Sehingga nilai-nilai yang menjadi pegangan orang asli Papua muda terkikis.Oleh krena itu MRP dalam misi lembaga adanya berusahan membangun dan mengwujudkan harapan orang asli Papua.Dalam misi lembaga MRP menyebutkan bahwa menjamin teruwudnya peningkatan taraf hidup dan tingkat kesejahteraan di bidang sandang, pangan dan papan bagi orang asli Papua.

Selain itu MRP dalam misinya juga menyebutkan bahwaakan memaksimalkan keberadaan dan keberpihakan MRP sebagai lembaga Representasi Kultural masyarakat asal Papua lewat peran-peran advokasi, proteksi, penegakan dan pelestarian hak-hak dasar orang asli Papua dan sumber daya alam (SDA) Papua menuju kesejahteraan yang bermartabat. Dengan ada misi dari MRP dapat diketahui bahwa kesenjangan terhadapat pengelolaan sumber daya alam yang ada di Papua selama ini tidak berpihak kepada orang asli Papua secara penuh.

\section{Faktor-Faktor yang mempengaruhui pelaksanaan MRP dalam memperkuat tatakelola pemerintahan di Provinsi Papua Barat}

Dalam perjalanannya, MRP banyak mendapat tantangan dalam mengembalikan hak politik orang asli Papua yang telah di amanatkan oleh Udang-Undang Nomor 21 Tahun 2001 tentang Otonomi Khusus Bagi Provinsi Papua sebagaimana yang telah diubah dengan Undang-Undang Nomor 35 Tahun 2008, MRP Provinsi Papua Barat mendorong agar rekrutmen partai politik memprioritaskan orang asli Papua dan mendapatkan pertimbangan dari MRP. Adapun yang mejadi rekomendasi dari MRP yang juga telah disahkan dalam undang -undang tersebut, diataranya adalah setiap rekruitmen politik oleh partai politik di Provinsi Papupa dilakukan dengan memperioritaskan masyarakat asli Papua dan partai politik juga wajib meminta pertimbangan kepada MRP dalam hal seleksi dan rekruitmen politik partainya masing-masing.

\section{KESIMPULAN}

Hasil dari penelitian ini membuktikan bahwa kewenangan yang dimiliki oleh lembaga adat MRP Papua Barat sangat berperan dalam mendorong tata kelola pemerintahan yang baik di tanah Papua. Hal ini kita dapat lihat dari elemen regulatif, normatif, dan kultural-kognitif yang berlaku 
di Papua selama ini. Adapaun ketiga elemen itu bisa dilihat sebagai berikut di bawah ini:

a. Secara regulatif dalam penelitian ini lembaga adat MRP Papua Barat sangat maksimal dan terlaksana dengan baik dalam merealisaskan Peraturan Pemerintah Tentang Nomor 54 Tahun 2004 tentang majlis Rakyat Papua (Lembaran Negara Republik Indonesia tahun 2004 nomor 165). Hal ini bisa dilihat dalam penemuan penelitian ini bahwa lembaga adat yang memperjuangkan hak asli Papua mampua berkontribusi dengan baik. Adapun yang telah dilakukan oleh MRP selama ini diantaranya adalah melakukan rekonsilliasi terhadap hak-hak asli orang Papua serta mendorong adanya Perdasus dan mengawal pembangunan di Papua. Sehingga dapat disimpulkan bawah secara regulative kelembagaan MRP di papu masih terlaksana.

b. Secara Normatif dalam peneliti ini, membuktikan masih berlaku. Hal ini dibuktikan dengan nilai-nilai kehidupan dan kebudayaan masyarakat asli Papua, dengan mengembalikan Kepemimpinan Tradisional, Penguatan Kelembagaan Adat, dan Keteguhan nilai-nilai budaya Papua. Dikatakan berjalan peran lenbaga MRP dari element Kultural-Kognitif dalam tata kelolah pemerintah yang baik dapat di buktikan dengan program Revitaslisasi, Rekonstruksi, Reposisi peran Kelembagaan Masyarakat Adat (R3LMA). Dalam Good Governance sendiri di buktikan dengan Kerjasamanya MRP Papua barat dengan Pemerintah Provinsi hingga pemerintah Pusat yang dapat menghasilkan Perdasus.

c. Secara Kultural Kognitif dalam penelitian ini membuktikan bahwa nilainilai yang adat asli papua masih di pertahankan. Hal ini dibuktikan dengan memperioritaskan agenda rekonsiliasi yangsalah satu isinya pemulihan terhadap para leluhur orang asli Papua (suku-suku asli Papua) hingga kegenerasi pemuda sekarang dengan tujuan teruwujudnya marga dari setiap suku-suku dan wilayah budaya sesamna suku asli papua yang hidup berdampingan. Selain itu secara hat atas masyarakat Hukum Adat juga masih berlaku sampai sekarang.

\section{DAFTAR PUSTAKA}

\section{Buku:}

Bobi, 2002. Modul latihan Pelatihan Pengelolaan Perkotaan Tingkat Dasar: Permasalahan Keuangan, kelembagaan dan Peraturan. Yogyakarta: Magister Perencanaan Kota dan Daerah, UGM. 
518 Bungin, Burhan. 2003. Analisis data penelitian kualitatif, pemahaman filosofis dan metodologis kearah pemahaman metode aplikasi. Jakarta: PT. Grafindo Persada.

Dwiyanto, Agus. 2008. Mewujudkan Good Governance, Melalui Pelayanan Publik. Yogyakarta: Gadjah Mada University.

Effendi, Sofian. 2005. Membangun Budaya Birokrasi Untuk Good Governance. Makalah Seminar Lokakarya Nasional Reformasi Birokrasi Diselenggarakan Kantor Menteri Negara PAN 22 September 2005.

Etzioni, Amitai. 1982. Organisasi-organisasi Modern, Jakarta: UI Press Pustaka Bradjaguna.

Koirudin. 2005. Sketsa Kebijakan Desentralisasi di Indonesia: Format Masa Depan Otonomi Menuju Kemandirian daerah. Malang : Averros Press.

Lexy J., Moleong. 2010. Metodologi Penelitian Kuali tatif. Bandung : PT Remaja Rosdakarya.

North, North DC. Institutions, 1990. Institutional Change and Economic Performance. Cambridge University Press.

Phil A., Susanto, 1989. Komunikasi Dalam Teori dan Praktek, Bandungg: Binacipta.

Purwandanu, Didik. 2013. Efektivitas Dana Otonomi Khusus di Papua dan Papua Barat dalam Memo Kebijakan: PATTIRO.

Scott, W. R. Institutions and Organizations (Ideas and interest) Third Edition, (Stanford University: sage Publictions, 2008), hlm 48

Sumodiningrat, Gunawan. 1999. Pemberdayaan Masyarakat dan Jaringan Pengaman Sosial, Jakrta: PT Gramedia Pustaka Utama

Tony, dkk., 2003. Kelembagaan dan Kebijakan Dalam Pengembangan Agroforestri, World Forestry Center.

Wiryanto F. 1986. Membangun masyarakat, Bandung: Alumni.

Jurnal/tesis:

Adriana, Grahani, F, 2011. Menyorot Kedudukan Dan Fungsi Mrp (Majelis Rakyat Papua) Dalam Otonomi Khusus Di Papua. (jurnal)

Bonsapia, Sofia. 2008. Pelaksanaan tugas dan wewenang Majelis rakyat Papua menurut Otonomi khusus Papua. (tesis).

Firdausy, Ardiana G. (tanpa tahun). Menyorot Kedudukan dan fungsi MRP (Majelis Rakyat Papua) dalam Otonomi Khusus di Papua, (jurnal). 
Harian umum Bintang Papua, edisi kamis 20 maret 2014, Melalui http://www.bintangPapua.com/index.php/lain-lain/Papua/Papuabarat/item/14213-bram-siapa-pun-yang-korupsi-tempatnya-di-tahanan, diakses pada minggu, 07 juni 2015, pukul 11:32 WIB.

Harian umum Radar Sorong, edisi senin, 09 desember 2013, melalui http://www.radarsorong.com/index.php? mib=berita.detail\&id=1928 5, diakses pada minggu, 07 juni 2015, pukul 21:20 WIB.

Harian umum Sinar Haraman.co, edisi senin, 09 desember 2013. melaluihttp://sinarharapan.co/news/read/29254/mrppb-cederai-

kepemimpinan-Papua-barat, diakses pada minggu, 07 juni 2015, pukul 21:04 WIB.

Kuswanto, Goto, 2012. Pelaksanaan Good Governance di Indonesia. http://www.banyumaskab.go.id/read/1139/pelaksanaan-goodgovernance-di-indonesia\#.VTEqVkZg3IU. Diakses tanggal 17 april 2015, pukul 22.54 WIB.

Magal, Martinus, 2011. Peran MRP terhadap kebijakan pemerintah dala perlindungan masyarakat adat Papua, (jurnal).

Syahyuti, 2009. Tinjauan Sosiologis Terhadap Konsep Kelembagaan Dan Upaya Membangun Rumusan Yang Lebih Operasional, (Pusat Analisis Sosial Ekonomi dan Kebijakan Pertanian, Bogor) dalam www.kelembagaandas.wordpress.com/pengertian-

kelembagaan/syahyuti, diakses tanggal 23 April 2015, pukul 11.00 wita.

Winardi, 2003.

Organisasi

Sosial.

http://id.wikipedia.org/wiki/Organisasi_sosial, diakses tanggal 17 April 2015, pukul 15.00 wita.

\section{Regulasi:}

Keputusan MRP Nomor.III/KK-MRP/2009, Perlindungan, Pemberdayaan, Keberpihakan Orang Asli Papua.

Peraturan Pemerintah Republik Indonesia, No.54 tahun 2004 tentang "Majelis Rakyat Papua”.

Peraturan Pemerintah Provinsi Papua Nomor. 4 Tahun 2005 tentang tatacara pemilihan anggota MRP

Undang-Undang Nomor 22 Tahun 1999 tentang Pemerintahan Daerah.

Undang-Undang Nomor 21 Tahun 2001 tentang Otonomi Khusus bagi Provinsi Papua. 